UDK 528.14

\title{
GPS VIRTUALIOSIOS REFERENCINĖS STOTIES REGRESINIO PROGNOZINIO MODELIO EKSPERIMENTINIAI TYRIMAI
}

\author{
Jonas Skeivalas, Robertas Dargis \\ Geodezijos ir kadastro katedra, Vilniaus Gedimino technikos universitetas, \\ Sauletekio al. 11, LT-10223 Vilnius, Lietuva \\ El.paštas Jonas.Skeivalas@ap.vgtu.lt,robertas@eika.lt
}

Iteikta 200707 27, priimta 20070927

\begin{abstract}
Santrauka. Straipsnyje pristatomi eksperimentiniai GPS metodu nustatytu taškų koordinačių pataisų tikslumo tyrimai, sudarant GPS virtualiųjų stočių regresinius prognozinius modelius. Regresinių prognozinių lygčių parametrų reikšmès apskaičiuojamos mažiausiujų kvadratų metodu, taikant kolokaciją ir žinomas tikslias GPS referencinių stočių koordinates bei išmatuotų atitinkamų GPS dydžių reikšmes. GPS vartotojo imtuvu išmatuotų prognozinių koordinačių pataisos skaičiuojamos pagal virtualiosiose stotyse sudarytus regresinius modelius, taikant apskaičiuotas parametrų reikšmes. Pagal prognozinius modelius nustatytų GPS vartotojo imtuvo prognozinių koordinačių tikslumas ivertinamas jų kovariacijų matricų įverčiais.
\end{abstract}

Reikšminiai žodžiai: GPS referencinès stotys, regresija, kovariacija, prognozè.

\section{Ivadas}

Straipsnyje siūlomas GPS virtualiujuc stočiu regresinis prognozinis modelis GPS vartotojo imtuvu išmatuotu taškų koordinačių pataisoms skaičiuoti. Regresinių lygčių parametrų reikšmès nustatomos mažiausiujų kvadratų metodu, taikant kolokacija ir žinomas GPS referencinių stočių koordinačių pataisas bei šių stočių geodezinès padėties duomenis. GPS virtualiujuc stočiu regresiniams prognoziniams modeliams sudaryti naudotasi Lietuvos 1-osios ir 2-osios klasių GPS tinklų matavimų duomenimis. Skaičiavimams atlikti parengtos kompiuterinès programos Matlab programinio paketo aplinkoje. Taikant GPS virtualiosios stoties modeli analizuojamas GPS vartotojo imtuvu nustatytų taškų prognozinių koordinačių tikslumas.

\section{Regresinio kolokacinio modelio teorinio principo apžvalga}

Troposferos ir jonosferos itakai GPS matavimu rezultatams eliminuoti yra sudaromas GPS referenciniu stočių tinklas [1-4]. Kadangi GPS referencinès stotys įrengiamos taškuose, kurių koordinatès tiksliai žinomos (su keleto milimetru ar centimetru klaidomis), tai kiekviena GPS referencinè stotis pagal priimtus dirbtiniu Žemès palydovų (DŽP) kodinius ir nešlio signalus gali apskaičiuoti apytiksliai išmatuotų koordinačių, pseudoatstumų bei nešlio fazių skirtumų pataisas. GPS vartotojas, taikydamas GPS referencinių stočių transliuojamas šių dydžių pataisas GPS virtualiosios stoties modelio pavidalu, apskaičiuoja tikslias savo imtuvo koordinates pagal išmatuotus apytikslius atitinkamus dydžius.

GPS virtualiosios referencinès stoties modelio parametrams skaičiuoti sudaroma parametrinių pataisu lygčių sistema blokinių matricu pavidalu $[5,6]$ :

$$
V=A \tau-\delta F_{0}=\left(\begin{array}{cc}
A_{u} & A_{e} \\
0 & E
\end{array}\right)\left(\begin{array}{l}
\tau_{u} \\
\tau_{e}
\end{array}\right)-\left(\begin{array}{c}
\delta F \\
\delta H_{e}
\end{array}\right)
$$

čia $V=\left(V_{u}^{T} V_{e}^{T}\right)^{T}, \quad \delta F_{0}=\left(\delta F^{T} \delta H_{e}^{T}\right)^{T}-$ laisvujų narių vektorius, $\tau=\left(\tau_{u}^{T} \tau_{e}^{T}\right)^{T}$ - nustatomu parametrų vektorius, $\boldsymbol{V}_{\boldsymbol{u}}=\boldsymbol{\delta} \tilde{\boldsymbol{F}}-\boldsymbol{\delta} \boldsymbol{F}-$ tiksliai išmatuotų dydžių išlygintujuc pataisų vektorius kaip išlygintuju ir tikslių dydžių vektorių skirtumas, $\boldsymbol{V}_{\boldsymbol{e}}=\tilde{\boldsymbol{H}}_{\boldsymbol{e}}-\boldsymbol{H}_{\boldsymbol{e}}-$ tiksliai išmatuotų elipsoidinių aukščių išlygintujų pataisų vektorius kaip išlygintujuc ir tikslių elipsoidinių aukščių vektorių skirtumas, $\delta \boldsymbol{F}=\overline{\boldsymbol{F}}-\boldsymbol{F}-$ tikslių ir apytiksliai išmatuotų dydžių skirtumų vektorius, $\delta \boldsymbol{H}_{\boldsymbol{e}}=\overline{\boldsymbol{H}}_{\boldsymbol{e}}-\boldsymbol{H}_{\boldsymbol{e}}-$ tikslių ir apytiksliai išmatuotų elipsoidinių aukščių skirtumų vektorius.

Parametrinių lygčių koeficientų matricoms $\boldsymbol{A}_{\boldsymbol{u}}$ ir $\boldsymbol{A}_{\boldsymbol{e}}$ sudaryti taikomos redukuotosios apytikrès epochiniu matavimų metu nustatytos referencinių stočių koordinatès ir elipsoidiniai aukščiai.

Parametrinių pataisų lygčių sistema (1) sprendžiama mažiausiujuc kvadratų metodu, ir gaunami GPS referencinių stočių tiksliai išmatuotų dydžių (koordinačių, nešlio fazių skirtumų ir pseudoatstumu) išlygintujų 
reikšmių vektorius $\left(\delta \tilde{\boldsymbol{F}}=\delta \boldsymbol{F}+\boldsymbol{V}_{\boldsymbol{u}}\right)$ bei parametrų reikšmių vektorius $\tau$ [5].

Parametrų reikšmių vektorius $\tau$ skaičiuojamas iš normalinių lygčių sistemos:

$$
\tau=N^{-1} A^{T} P \cdot \delta F_{0},
$$

čia $\boldsymbol{N}=\boldsymbol{A}^{\boldsymbol{T}} \boldsymbol{P A}$ - normalinių lygčių koeficientų matrica, $\boldsymbol{P}=\left(\boldsymbol{P}_{\boldsymbol{u}} \boldsymbol{P}_{\boldsymbol{e}}\right)_{\text {diag }}-$ referencinių stočių atitinkamų dydžiu pataisų $\delta \boldsymbol{F}_{\boldsymbol{i}}$ ir elipsoidinių aukščiu pataisų $\boldsymbol{\delta} \boldsymbol{H}_{\boldsymbol{e}, \boldsymbol{i}}$ svorių matrica.

Normalinių lygčių koeficientų matricą $N$ rašome blokiniu pavidalu:

$$
\begin{aligned}
& \boldsymbol{N}=\left(\begin{array}{cc}
\boldsymbol{A}_{u} & \boldsymbol{A}_{\boldsymbol{e}} \\
0 & \boldsymbol{E}
\end{array}\right)^{\boldsymbol{T}}\left(\begin{array}{cc}
\boldsymbol{P}_{u} & \\
& \boldsymbol{P}_{e}
\end{array}\right)\left(\begin{array}{cc}
\boldsymbol{A}_{u} & \boldsymbol{A}_{\boldsymbol{e}} \\
0 & \boldsymbol{E}
\end{array}\right)= \\
& \left(\begin{array}{c|c}
A_{u}^{\boldsymbol{T}} \boldsymbol{P}_{u} A_{u} & \boldsymbol{A}_{u}^{\boldsymbol{T}} \boldsymbol{P}_{u} A_{e} \\
\boldsymbol{A}_{\boldsymbol{e}}^{\boldsymbol{T}} \boldsymbol{P}_{u} A_{u} & \boldsymbol{A}_{\boldsymbol{e}}^{\boldsymbol{T}} \boldsymbol{P}_{u} A_{e}+P_{e}
\end{array}\right)=\left(\begin{array}{cc}
\boldsymbol{N}_{11} & \boldsymbol{N}_{12} \\
\boldsymbol{N}_{21} & \boldsymbol{N}_{22}
\end{array}\right) .
\end{aligned}
$$

Apskaičiuotų parametrų reikšmių vektoriaus $\tau$ tikslumas įvertinamas jų kovariacijų matrica $\boldsymbol{K}_{\tau}$ :

$$
\boldsymbol{K}_{\tau}=\sigma_{0}^{2} \boldsymbol{N}^{-1}=\sigma_{0}^{2}\left(\begin{array}{ll}
\boldsymbol{Q}_{11} & \boldsymbol{Q}_{12} \\
\boldsymbol{Q}_{21} & \boldsymbol{Q}_{22}
\end{array}\right),
$$

čia $\sigma_{0}-$ matavimo rezultato, kurio svoris lygus vienetui, standartinis nuokrypis.

Standartinio nuokrypio ivertis $m_{0}$ gaunamas iš formulès:

$$
\sigma_{0}^{2} \approx m_{0}^{2}=\frac{1}{n-k} \boldsymbol{V}^{\boldsymbol{T}} \boldsymbol{P} \boldsymbol{V}
$$

\section{GPS vartotojo imtuvo koordinačių pataisų prognozinis modelis}

GPS virtualiosios referencinès stoties regresinio modelio parametrų reikšmių vektorius $\tau$ taikomas GPS vartotojo imtuvu nustatomų taškų koordinačių pataisų prognoziniam modeliui sudaryti. Modelis igauna išraišką:

$$
\delta \boldsymbol{T}_{v}=\boldsymbol{A}_{v} \boldsymbol{\tau}=\boldsymbol{A}_{v u} \boldsymbol{\tau}_{u}+\boldsymbol{A}_{v e} \boldsymbol{\tau}_{e},
$$

čia $\delta \boldsymbol{T}_{\boldsymbol{v}}-G P S$ imtuvu nustatomų taškų koordinačių pataisų vektorius, $\boldsymbol{A}_{\boldsymbol{v}}$ - koeficientų matrica, sudaroma pagal vartotoju imtuvais nustatytas apriorines redukuotąsias taškų koordinates $\left(\boldsymbol{X}_{v}^{\prime}, \boldsymbol{Y}_{v}^{\prime}, \boldsymbol{Z}_{v}^{\prime}\right)$, taikant išraišką (8).

GPS vartotojų imtuvų prognozinių koordinačių vektorius gaunamas taip:

$$
\tilde{T}_{v}=T_{v}+\delta T_{v}
$$

čia $T_{v} \rightarrow\left(T_{1}, T_{2}, \ldots, T_{n}\right)^{T}, T_{i} \rightarrow\left(X_{i}, Y_{i}, Z_{i}\right)^{T}, n-G P S$ vartotojo imtuvų skaičius.

GPS vartotojo imtuvo koordinačių pataisu prognoziniam modeliui naudojamas parametrų reikšmių vektorius $\tau$, apskaičiuotas pagal GPS virtualiosios referencinès stoties modeli, sudarytą taikant koordinačiu korekciją. Šiuo atveju matricos $\boldsymbol{A}_{\boldsymbol{u}}$ ir $\boldsymbol{A}_{\boldsymbol{e}}$ yra tokio blokinio pavidalo $[7,8]$ :

$$
\boldsymbol{A}_{u}=\left(\begin{array}{c}
\boldsymbol{A}_{u_{1}} \\
\vdots \\
\boldsymbol{A}_{u_{r}}
\end{array}\right), \boldsymbol{A}_{e}=\left(\boldsymbol{A}_{e_{1}}, \ldots, \boldsymbol{A}_{\boldsymbol{e}_{r}}\right)_{\mathrm{diag}}
$$

čia $i=1,2, \ldots, r$-referencinių stočių eilès numeriai.

Blokinès dalys $\boldsymbol{A}_{\boldsymbol{u}_{\boldsymbol{i}}}$ sudaromos taikant referenciniu stočių redukuotąsias koordinates $\left(\boldsymbol{X}_{\boldsymbol{i}}^{\prime}, \boldsymbol{Y}_{\boldsymbol{i}}^{\prime}, \boldsymbol{Z}_{\boldsymbol{i}}^{\prime}\right)=$ $\left\{\left(x_{i}-x_{\text {vid. }}\right) \cdot 10^{-5},\left(y_{i}-y_{\text {vid } .}\right) \cdot 10^{-5},\left(z_{i}-z_{\text {vid. }}\right) \cdot 10^{-5}\right\}$,

$$
A_{u_{i}}=\left(\begin{array}{c}
A_{x_{i}} \\
A_{y_{i}} \\
A_{z_{i}}
\end{array}\right)=\left(\begin{array}{cccccc}
X_{i}^{\prime} & Y_{i}^{\prime} & Z_{i}^{\prime} & X_{i}^{\prime 2} & 0 & 0 \\
X_{i}^{\prime} & Y_{i}^{\prime} & Z_{i}^{\prime} & 0 & \boldsymbol{Y}_{i}^{\prime 2} & 0 \\
X_{i}^{\prime} & Y_{i}^{\prime} & Z_{i}^{\prime} & 0 & 0 & Z_{i}^{\prime 2}
\end{array}\right)
$$

taikant 6 parametrų modeli.

Matricos $\boldsymbol{A}_{\boldsymbol{e}}$ blokiné dalis $\boldsymbol{A}_{\boldsymbol{e}_{\boldsymbol{i}}}$ yra lygi

$$
\boldsymbol{A}_{\boldsymbol{e}_{i}}=\left(\begin{array}{cccccc}
0 & 0 & \ldots & \boldsymbol{H}_{\boldsymbol{e}_{i}}^{\prime} & \ldots & 0 \\
0 & 0 & \ldots & \boldsymbol{H}_{\boldsymbol{e}_{i}}^{\prime} & \ldots & 0 \\
0 & 0 & \ldots & \boldsymbol{H}_{\boldsymbol{e}_{i}}^{\prime} & \ldots & 0
\end{array}\right)
$$

čia $\boldsymbol{H}_{\boldsymbol{e}_{\boldsymbol{i}}}^{\prime}=\boldsymbol{H}_{\boldsymbol{e}} \cdot 10^{-2}-$ redukuotasis elipsoidinis aukštis.

GPS vartotojo imtuvo koordinačių pataisu vektoriaus $\delta \boldsymbol{T}_{\boldsymbol{v}}$ kovariaciju matrica $\boldsymbol{K}_{\delta \boldsymbol{T}_{\boldsymbol{v}}}$ yra šio pavidalo:

$$
\boldsymbol{K}_{\delta \boldsymbol{T}_{v}}=\boldsymbol{A}_{v u} \boldsymbol{K}_{\tau_{u}} \boldsymbol{A}_{v u}^{T}=\sigma_{0}^{2} \boldsymbol{A}_{v u} \boldsymbol{Q}_{11} \boldsymbol{A}_{v u}^{T}
$$

\section{Eksperimentinio modeliavimo rezultatai}

GPS virtualiosios referencinès stoties regresiniam modeliui sudaryti buvo panaudoti Lietuvos 1-osios ir 2-osios klasių GPS tinklo matavimu duomenys (19931995 m. GPS dienos). Pagal šiuos duomenis kiekvienai GPS tinklo klasei buvo sudaryta po keturis GPS referencinių stočių klasterius: Vakarų, Rytų, Pietų ir Šiaurès Lietuvos dalyse. Pirmosios klasès klasteriai buvo sudaryti iš 3 referencinių stočių. Tokios buvo GPS tinklo matavimo duomenų teikiamos galimybès, nes regresiniams modeliams sudaryti yra būtini GPS matavimu rezultatai, gauti tais pačiais laiko momentais, t. y. tomis pačiomis epochomis. Pirmosios klasès 
klasteriuose naudota po vieną kontrolinę vartotojo stoti, o antrosios klasès - po 2 ir 3 kontrolines vartotojo stotis. Pirmosios klasès klasteriuose atstumai tarp GPS referenciniu stočiu - 50-80 km, o antrosios klasès klasteriuose - 10-20 km. Skirtumai GPS pirmosios ir antrosios klasių klasteriuose tarp tiksliu referencinès stoties koordinačių ir pavienèse epochose apytiksliai išmatuotų - nuo keleto metrų iki keleto dešimčių metrų. Maždaug tokio pat didumo skirtumai buvo ir kontrolinèse vartotojo stotyse.

GPS virtualiujų referencinių stočių 6-osios ir 9-osios eilès regresiniai modeliai buvo sudaryti taikant paprastąsias regresines lygtis bei regresines lygtis su papildomomis kolokacinėmis lygtimis. Skaičiavimai atlikti pagal sudarytą kompiuterinę programą VRSk.m, panaudojus Matlab programinio paketo operatorius. Variantuose apskaičiuotieji GPS virtualiuju stočiu regresiniu modeliu parametrai buvo naudojami GPS vartotojo imtuvo koordinačių nustatymo prognoziniam modeliui sudaryti (6). Kontrolinių GPS vartotojo imtuvu apskaičiuotu prognozinių koordinačių nuokrypiai nuo jų tikrujų koordinačių parodyti 1-6 lentelèse.

1 lentelè. 1-osios klasès klasterio kontrolinio GPS vartotojo imtuvo (Piliuona, Pietų Lietuva) prognozinių koordinačių nuokrypiai, taikant modeli VRS.m

Table 1. Prognostics coordinates deviations of $1^{\text {st }}$ class cluster of GPS user control recipient (Piliuona, South Lithuania)

\begin{tabular}{|c|c|c|c|c|c|c|}
\hline \multirow[b]{3}{*}{ Epochos } & \multicolumn{6}{|c|}{ Koordinačių nuokrypiai, kai taikomas } \\
\hline & \multicolumn{3}{|c|}{$\begin{array}{l}\text { 6-osios eilès regresinis } \\
\text { modelis, } \mathrm{m}\end{array}$} & \multicolumn{3}{|c|}{$\begin{array}{c}\text { 9-osios eilès regresinis } \\
\text { modelis, } \mathrm{m}\end{array}$} \\
\hline & $\delta X, \mathrm{~m}$ & $\delta Y, \mathrm{~m}$ & $\delta Z, \mathrm{~m}$ & $\delta X, \mathrm{~m}$ & $\delta Y, \mathrm{~m}$ & $\delta Z, \mathrm{~m}$ \\
\hline 1 & $-0,1411$ & $-0,0302$ & $-0,6175$ & $-1,3441$ & $-0,8982$ & $-1,9105$ \\
\hline 2 & 0,5428 & 0,3007 & $-0,4643$ & 0,9348 & 0,0767 & $-0,1283$ \\
\hline 3 & $-0,0108$ & $-0,1931$ & $-0,1075$ & $-0,6878$ & $-0,6661$ & $-0,8845$ \\
\hline 4 & $-0,0006$ & 0,0910 & $-0,4872$ & $-0,6946$ & $-0,2130$ & $-0,8402$ \\
\hline 5 & 0,0677 & 0,1858 & 0,0029 & 0,3007 & 0,2758 & 0,3969 \\
\hline 6 & 0,2032 & $-0,1461$ & $-0,4074$ & 0,7642 & 0,0899 & 0,0336 \\
\hline
\end{tabular}

2 lentelè. 1-osios klasès klasterio kontrolinio GPS vartotojo imtuvo (Padvarninkai, Šiaurès Lietuva) prognozinių koordinačių nuokrypiai, taikant modeli VRS.m

Table 2. Prognostics coordinates deviations of $1^{\text {st }}$ class cluster of GPS user control recipient (Padvarninkai, North Lithuania)

\begin{tabular}{|c|r|r|r|r|r|r|}
\hline \multirow{4}{*}{ Epochos } & \multicolumn{5}{|c|}{ Koordinačiu nuokrypiai, kai taikomas } \\
\cline { 2 - 7 } & \multicolumn{3}{|c|}{$\begin{array}{c}6-\text { osios eilès regresinis } \\
\text { modelis, } \mathrm{m}\end{array}$} & \multicolumn{3}{c|}{$\begin{array}{c}\text { 9-osios eilès regresinis } \\
\text { modelis, } \mathrm{m}\end{array}$} \\
\cline { 2 - 7 } & $\delta, \mathrm{m}$ & $\delta Y, \mathrm{~m}$ & $\delta Z, \mathrm{~m}$ & $\delta X, \mathrm{~m}$ & $\delta Y, \mathrm{~m}$ & $\delta Z, \mathrm{~m}$ \\
\hline 1 & 0,1726 & 0,4301 & 0,0584 & 0,4996 & $-0,6379$ & 0,1564 \\
\hline 2 & $-0,0017$ & 0,1286 & $-0,2717$ & 0,0943 & $-0,8534$ & $-0,8937$ \\
\hline 3 & $-0,2527$ & 0,3690 & 0,1417 & $-0,1767$ & 0,4070 & 0,2327 \\
\hline 4 & 0,2019 & $-0,7126$ & 0,1713 & 0,0789 & $-0,1436$ & 0,2003 \\
\hline 5 & 0,3406 & 0,1650 & $-0,4754$ & 0,4456 & $-0,1850$ & $-0,7134$ \\
\hline 6 & $-0,3167$ & 0,3515 & 0,0660 & $-0,2027$ & $-0,6675$ & $-0,3180$ \\
\hline
\end{tabular}

3 lentelè. 1-osios klasés klasterio kontrolinio GPS vartotojo imtuvo (Piliuona, Pietu Lietuva) prognozinių koordinačių nuokrypiai, taikant modeli VRSk.m

Table 3. Prognostics coordinates deviations of $1^{\text {st }}$ class cluster of GPS user control recipient (Piliuona, South Lithuania)

\begin{tabular}{|c|c|c|c|c|c|c|}
\hline \multirow[b]{3}{*}{ Epochos } & \multicolumn{6}{|c|}{ Koordinačių nuokrypiai, kai taikomas } \\
\hline & \multicolumn{3}{|c|}{$\begin{array}{l}\text { 6-osios eilès regresinis } \\
\text { kolokacinis modelis, m }\end{array}$} & \multicolumn{3}{|c|}{$\begin{array}{r}\text { 9-osios eilès regresinis } \\
\text { kolokacinis modelis, } m\end{array}$} \\
\hline & $\delta X, \mathrm{~m}$ & $\delta Y, \mathrm{~m}$ & $\delta Z, \mathrm{~m}$ & $\delta X, \mathrm{~m}$ & $\delta Y, \mathrm{~m}$ & $\delta Z, \mathrm{~m}$ \\
\hline 1 & $-0,4401$ & 0,0498 & $-0,8665$ & 0,4799 & 0,9778 & $-0,2845$ \\
\hline 2 & 0,2398 & 0,1497 & $-0,7483$ & 1,0388 & 0,4577 & $-0,0733$ \\
\hline 3 & $-0,2298$ & $-0,0891$ & $-0,2845$ & 0,6362 & 0,5309 & 0,5765 \\
\hline 4 & $-0,2666$ & 0,0970 & $-0,7182$ & $-0,1306$ & 0,5300 & $-0,3192$ \\
\hline 5 & 0,2487 & 0,1488 & 0,1559 & $-0,4243$ & $-0,3902$ & $-0,2751$ \\
\hline 6 & 0,2712 & $-0,0011$ & $-0,3294$ & 0,7832 & 0,2259 & $-0,0224$ \\
\hline
\end{tabular}

4 lentelè. 1-osios klasès klasterio kontrolinio GPS vartotojo imtuvo (Padvarninkai, Šiaurès Lietuva) prognozinių koordinačių nuokrypiai, taikant modeli VRSk.m

Table 4. Prognostics coordinates deviations of $1^{\text {st }}$ class cluster of GPS user control recipient (Padvarninkai, North Lithuania)

\begin{tabular}{|c|c|c|c|c|c|c|}
\hline \multirow{2}{*}{ Epochos } & \multicolumn{5}{|c|}{ Koordinačių nuokrypiai, kai taikomas } \\
\cline { 2 - 7 } & \multicolumn{3}{|c|}{$\begin{array}{c}\text { 6-osios eilès regresinis } \\
\text { kolokacinis modelis, } \mathrm{m}\end{array}$} & \multicolumn{2}{c|}{$\begin{array}{c}\text { 9-osios eilès regresinis } \\
\text { kolokacinis modelis, } \mathrm{m}\end{array}$} \\
\cline { 2 - 8 } & $\delta X, \mathrm{~m}$ & $\delta Y, \mathrm{~m}$ & $\delta Z, \mathrm{~m}$ & $\delta X, \mathrm{~m}$ & $\delta Y, \mathrm{~m}$ & $\delta Z, \mathrm{~m}$ \\
\hline 1 & 0,8506 & 0,5931 & 0,7424 & 0,4996 & $-0,6379$ & 0,1564 \\
\hline 2 & 0,8003 & 0,3226 & 0,5373 & 0,0943 & $-0,8534$ & $-0,8937$ \\
\hline 3 & $-0,3377$ & 0,3520 & 0,0567 & $-0,1767$ & 0,4070 & 0,2327 \\
\hline 4 & $-0,1971$ & $-0,8076$ & $-0,2307$ & 0,0789 & $-0,1436$ & 0,2003 \\
\hline 5 & 0,5766 & 0,2120 & $-0,2374$ & 0,4456 & $-0,1850$ & $-0,7134$ \\
\hline 6 & 0,4903 & 0,5465 & 0,8800 & $-0,2027$ & $-0,6675$ & $-0,3180$ \\
\hline
\end{tabular}

5 lentelè. 2-osios klasès klasterio 3-jų kontrolinių GPS vartotojo imtuvų (Pietų Lietuva) prognozinių koordinačių nuokrypiai, kai $G P S$ virtualiosios stoties modelis iš 4 referencinių stočių, taikant modeli VRS.m

Table 5. Prognostics coordinates deviations of $2^{\text {nd }}$ class cluster of GPS user control recipient (South Lithuania) GPS virtual station models using 4 reference stations

\begin{tabular}{|c|c|c|c|c|c|c|}
\hline \multirow[b]{3}{*}{ Epochos } & \multicolumn{6}{|c|}{ Koordinačių nuokrypiai, kai taikomas } \\
\hline & \multicolumn{3}{|c|}{$\begin{array}{l}\text { 6-osios eilès regresinis } \\
\text { modelis, } m\end{array}$} & \multicolumn{3}{|c|}{$\begin{array}{c}\text { 9-osios eilès regresinis } \\
\text { modelis, } \mathrm{m}\end{array}$} \\
\hline & $\delta X, \mathrm{~m}$ & $\delta Y, \mathrm{~m}$ & $\delta Z, \mathrm{~m}$ & $\delta X, \mathrm{~m}$ & $\delta Y, \mathrm{~m}$ & $\delta Z, \mathrm{~m}$ \\
\hline & 0,0016 & 0,0036 & $-0,0042$ & $-0,0024$ & $-0,0004$ & $-0,0082$ \\
\hline \multirow[t]{3}{*}{1} & $-0,0093$ & 0,0320 & 0,0010 & $-0,0053$ & 0,0000 & 0,0000 \\
\hline & 0,0020 & 0,0090 & $-0,0078$ & $-0,0010$ & $-0,0010$ & $-0,0308$ \\
\hline & 0,1038 & $-0,0543$ & 0,0257 & 0,1448 & $-0,0303$ & 0,0507 \\
\hline \multirow[t]{3}{*}{2} & 0,1190 & $-0,0176$ & $-0,0384$ & $-0,3790$ & 0,2974 & $-0,0314$ \\
\hline & 0,1107 & $-0,0593$ & 0,0018 & 0,2947 & $-0,0243$ & 0,1248 \\
\hline & $-0,0598$ & 0,0613 & $-0,0080$ & $-0,1278$ & 0,0223 & $-0,0480$ \\
\hline \multirow[t]{3}{*}{3} & 0,0395 & 0,3922 & 0,0645 & 1,4725 & 0,0562 & $-0,1045$ \\
\hline & $-0,0169$ & 0,1346 & 0,0268 & $-0,6059$ & $-0,0174$ & $-0,2012$ \\
\hline & $-0,0665$ & $-0,0094$ & $-0,0382$ & $-0,0855$ & $-0,0174$ & $-0,0582$ \\
\hline \multirow[t]{2}{*}{4} & 0,0971 & $-0,1024$ & $-0,0002$ & 0,1531 & $-0,2984$ & 0,0568 \\
\hline & 0,0630 & $-0,1661$ & $-0,0324$ & 0,0680 & $-0,1371$ & $-0,0554$ \\
\hline
\end{tabular}


5 lentelès pabaiga

\begin{tabular}{|r|r|r|r|r|r|r|}
\hline & 0,1371 & $-0,0534$ & 0,0404 & 0,1021 & $-0,0724$ & 0,0184 \\
\hline 5 & $-0,0421$ & $-0,0921$ & $-0,0177$ & 0,6539 & $-0,2771$ & $-0,0887$ \\
\hline & 0,0388 & 0,0155 & 0,0531 & $-0,2412$ & $-0,0475$ & $-0,0509$ \\
\hline & $-0,0862$ & 0,1010 & $-0,0045$ & $-0,0322$ & 0,1330 & 0,0535 \\
\hline 6 & 0,3868 & 0,1624 & 0,0192 & 0,1208 & 0,6914 & $-0,0708$ \\
\hline & 0,1907 & $-0,0809$ & $-0,0142$ & 0,2517 & $-0,0919$ & 0,1338 \\
\hline
\end{tabular}

6 lentelè. 2-osios klasès klasterio 2-jų kontrolinių GPS vartotojo imtuvų (Pietų Lietuva) prognozinių koordinačių nuokrypiai, kai GPS virtualiosios stoties modelis iš 4 referencinių stočių, taikant modeli VRSk.m

Table 6. Prognostics coordinates deviations of $2^{\text {nd }}$ class cluster of $G P S$ user control recipient (South Lithuania) GPS virtual station models using 4 reference stations

\begin{tabular}{|c|c|c|c|c|c|c|}
\hline \multirow[b]{3}{*}{ Epochos } & \multicolumn{6}{|c|}{ Koordinačių nuokrypiai, kai taikomas } \\
\hline & \multicolumn{3}{|c|}{$\begin{array}{l}\text { 6-osios eilès regresinis } \\
\text { kolokacinis modelis, } m\end{array}$} & \multicolumn{3}{|c|}{$\begin{array}{c}\text { 9-osios eilès regresinis } \\
\text { kolokacinis modelis, } \mathrm{m}\end{array}$} \\
\hline & $\delta X, \mathrm{~m}$ & $\delta Y, \mathrm{~m}$ & $\delta Z, \mathrm{~m}$ & $\delta X, \mathrm{~m}$ & $\delta Y, \mathrm{~m}$ & $\delta Z, \mathrm{~m}$ \\
\hline \multirow[t]{2}{*}{1} & $-0,0169$ & $-0,016$ & $-0,0148$ & $-0,0219$ & $-0,015$ & $-0,0438$ \\
\hline & $-0,0173$ & $-0,0198$ & $-0,0245$ & $-0,0103$ & $-0,0128$ & $-0,0215$ \\
\hline \multirow[t]{2}{*}{2} & 0,0404 & 0,1516 & $-0,008$ & 0,0464 & $-0,0864$ & $-0,086$ \\
\hline & $-0,0799$ & 0,0151 & $-0,0845$ & $-0,1479$ & $-0,0929$ & $-0,1655$ \\
\hline \multirow[t]{2}{*}{3} & $-0,1075$ & $-0,1267$ & $-0,1083$ & $-0,0735$ & $-0,1197$ & $-0,2323$ \\
\hline & $-0,0746$ & $-0,0721$ & $-0,0918$ & $-0,0236$ & $-0,0271$ & $|-0,0698|$ \\
\hline \multirow[t]{2}{*}{4} & 0,3121 & 0,4344 & 0,2074 & $-0,1879$ & 0,2154 & 0,6344 \\
\hline & $-0,0227$ & 0,0671 & $-0,008$ & $-0,4227$ & $-0,2689$ & $-0,229$ \\
\hline \multirow[t]{2}{*}{5} & $-0,1697$ & $-0,3095$ & $-0,1221$ & 0,2933 & $-0,0485$ & $-0,7981$ \\
\hline & $-0,0817$ & $-0,1525$ & $\mid-0,1432$ & 0,3873 & 0,2675 & 0,1118 \\
\hline \multirow[t]{2}{*}{6} & $-0,0996$ & $-0,0062$ & 0,0277 & $-0,8486$ & $-0,0812$ & 0,4517 \\
\hline & 0,1704 & $-0,2452$ & $-0,0569 \mid$ & $-0,2656$ & $-0,5432$ & $-0,2639$ \\
\hline
\end{tabular}

Kontroliniu GPS vartotojo imtuvų prognoziniu koordinačių tikslumas ivvertinamas jų kovariacijų matrica (9). Pietu Lietuvos 2-osios klasès klasterio kontroliniu GPS vartotojo imtuvų prognozinių koordinačių vektoriaus kovariacijų matricos ivertis parodytas 7 lentelèje. Šios lentelès duomenys rodo, kad dviejų GPS imtuvų koordinačių standartinių nuokrypių iverčiai 3,5$8,5 \mathrm{~cm}$ svyruoja.

Palyginus lentelèse pateiktus duomenis matyti, kad 1-osios klasès klasterių kontrolinių GPS vartotojo imtuvų prognozinių koordinačių nuokrypiai nuo tikrujų reikšmių kinta nuo keleto centimetru iki keleto decimetru, o 2-osios klasès klasteriu - nuo keleto milimetru iki keleto centimetrų (pavienèse epochose - iki keleto decimetru). Lemia tai, kad esant 1-osios klasès klasteriams žymiai didesni atstumai $(50-80 \mathrm{~km})$ tarp referencinių stočių bei tarp referenciniu stočiu ir vartotojo imtuvų nei kai klasteriai 2-osios klasès (10-20 km).
7 lentelè. Pietų Lietuvos 2-osios klasès klasterio 2-jų kontrolinių GPS vartotojo imtuvų prognozinių koordinačių vektoriaus matricos ivertis

Table 7. The estimation of prognostics coordinates vectors matrixes of GPS user control recipient of $2^{\text {nd }}$ class cluster in South Lithuania

\begin{tabular}{|r|r|r|r|r|r|}
\hline 0,0014 & 0,0013 & 0,0014 & $\begin{array}{r}-1,79 \\
\mathrm{e}-005\end{array}$ & $-0,0010$ & $\begin{array}{r}4,72 \\
\mathrm{e}-005\end{array}$ \\
\hline 0,0013 & 0,0013 & 0,0013 & $\begin{array}{r}9,98 \\
\mathrm{e}-006\end{array}$ & $-0,0009$ & $\begin{array}{r}7,03 \\
\mathrm{e}-005\end{array}$ \\
\hline 0,0014 & 0,0013 & 0,0014 & $\begin{array}{r}-1,70 \\
\mathrm{e}-005\end{array}$ & $-0,0010$ & $\begin{array}{r}8,32 \\
\mathrm{e}-005\end{array}$ \\
\hline$-1,79$ & 9,98 & $-1,70$ & 0,0013 & 0,0018 & 0,0012 \\
$\mathrm{e}-005$ & $\mathrm{e}-006$ & $\mathrm{e}-005$ & & & \\
\hline$-0,0010$ & $-0,0009$ & $-0,0010$ & 0,0018 & 0,0080 & 0,0016 \\
\hline 4,72 & 7,03 & 8,32 & 0,0012 & 0,0016 & 0,0013 \\
$\mathrm{e}-005$ & $\mathrm{e}-005$ & $\mathrm{e}-005$ & & & \\
\hline
\end{tabular}

Žemès paviršiaus taškuose nutolusiuose vienas nuo kito dideliu atstumu, labai skiriasi troposferos ir jonosferos parametrų reikšmès. Didžiausią ịtaką GPS matavimu rezultatu tikslumui turi jonosfera, todèl, tolstant GPS vartotojo imtuvui nuo referencinių stočių, didèja GPS vartotojo imtuvu nustatomų koordinačiu klaidos [8].

\section{Išvados}

1. Atlikti eksperimentiniai skaičiavimai, taikant virtualiosios GPS referencines stoties 6-osios ir 9-osios eilès regresinius modelius bei regresinius modelius su papildomomis kolokacinèmis lygtimis. Nustatyta GPS vartotojo imtuvo prognozinių koordinačių nuokrypių nuo tikrujų reikšmių kaita keičiant modelio variantus.

2. GPS vartotojo imtuvo prognoziniu koordinačiu nuokrypiai, taikant 6-osios eilès regresini modeli, yra maždaug tokio paties didumo kaip ir taikant 9-osios eilès modeli. Regresinis kolokacinis modelis yra nežymiai mažesnio tikslumo nei paprastasis regresinis modelis.

3. Didinant atstumą tarp GPS vartotojo imtuvo ir GPS referenciniu stočiu dideja vartotojo imtuvo prognozinių koordinačių nuokrypiai nuo tikrujų reikšmių. Taikant siūlomą regresini modeli, nutolus vartotojo imtuvui iki $20 \mathrm{~km}$ nuo referencinių stočių, GPS vartotojo imtuvo prognozinių koordinačių nuokrypiai nuo tikrujų reikšmių yra nuo keleto milimetrų iki keleto centimetrų.

\section{Literatūra}

1. WANNINGER, L. Virtuelle GPS-Referenzstationen für grossräumige kinematische Anwendungen. Zeitschrift für Vermessungswesen, 2003, No 3. Stuttgart: Verlag K. Witwer, S. 196-202.

2. HANKEMEIER, P. Der Satellitenpositionierungsdienst SAPOS in Deutschland. In Multifunktionale GNSS- 
3. Referenzstationsysteme für Europa. Workshop von 4-5. März 2002 in der Europäischen Akademie für städtische Umwelt. Berlin, 2002, S. 16-23.

4. TEUNISSEN, P. J. G. The parameter distributions of the integer GPS model. Journal of Geodesy, 2002, No 1 (76), p. 41-48.

5. GAO, Y. and LIU, Z. Z. Precise ionosphere modeling using regional GPS network data. Journal of Global Positioning Systems, 2002, Vol 1, No 1, p. 18-24.

6. SKEIVALAS, J. Regression model of virtual GPS reference. Geodesy and Cartography (Geodezija ir kartografija), 2006, Vol XXXII, No 4, p. 96-99 (in Lithuanian).

7. SKEIVALAS, J. The regression model of virtual GPS reference station by application of collocation method. Geodesy and Cartography (Geodezija ir kartografija), 2007, Vol XXXIII, No 1, p. 9-12 (in Lithuanian).

8. KOCH, K. R. Einführung in die Bayes-Statistik. BerlinHeidelberg: Springer-Verlag, 2000. 225 S.

9. SKEIVALAS, J. Accuracy determination of the coordinates augmentations of GPS vectors by measuring double phase shifts of the carrier. Geodesy and Cartography (Geodezija ir kartografija), 2003, Vol XXIX, No 4, p. 115-118 (in Lithuanian).
Jonas SKEIVALAS. Prof, Doctor Habil. Vilnius Gediminas Technical University. Dept of Geodesy and Cadastre, Saulètekio al. 11, LT-10223 Vilnius, Lithuania. $\mathrm{Ph}+37052744$ 703, Fax +370 52744 705,

e-mail: jonas.skeivalas@ap.vgtu.lt.

Author of two monographs and more than 130 scientific papers. Participated in many intern conferences and research visits to the Finish Geodetic Institute.

Research interests: processing of measurements with respect to tolerances, adjustment of geodetic networks.

Robertas DARGIS. Director UAB „Eika“, A. Goštauto g. 40A, LT-01112 Vilnius, Lithuania.

Dipl Eng (1984). President of the Lithuanian association of real estate developers.

Research interests: engineering geodesy, adjustment of geodetic networks. 